\title{
PERAN, HAK, DAN KEWAJIBAN GURU BESERTA UPAYA PENINGKATAN PROFESIONALISME GURU
}

\author{
Harun Ar Rasyid Lim Seong Been \\ Email: 2010111210029@mhs.ulm.ac.id \\ Program Studi Pendidikan Sejarah Fakultas Keguruan dan Ilmu Pendidikan \\ Universitas Lambung Mangkurat \\ Banjarmasin
}

\begin{abstract}
Abstrak
Guru adalah suatu profesi, yaitu suatu pekerjaan atau jabatan yang membutuhkan keahlian maupun keterampilan khusus. Guru dapat memenuhi syarat sebagai suatu profesi seperti memiliki organisasi profesi, kode etik profesi, dan jabatan yang lebih mementingkan layanan dibandingkan dengan keuntungan pribadi. Guru memiliki peran, hak, dan kewajiban yang dimiliki sebagaimana tercantum dalam UU No.14 Tahun 2005 tentang Guru dan Dosen. Guru harus mampu mengembangkan profesionalismenya dalam rangka meningkatkan mutu pendidikan nasional. Di samping itu, guru juga harus memiliki beberapa kompetensi sebagai bagian dari profesionalisme seorang guru. Kompetensikompetensi tersebut yaitu: kompetensi profesional, kompetensi pedagogic, kompetensi sosial, dan kompetensi kepribadian.
\end{abstract}

\section{PENDAHULUAN}

Profesi secara etimologi berasal dari kata profession (Inggris) yang berasal dari bahasa Latin profesus yang berarti "mampu atau ahli dalam suatu bentuk pekerjaan". Profesi dapat diartikan sebagai suatu pekerjaan atau jabatan yang menuntut keahlian, yang didapat melalui pendidikan dan latihan tertentu, menurut persyaratan khusus memiliki tanggung jawab dank kode etik tertentu. Pekerjaan yang bersifat profesional berbeda dengan pekerjaan lainnya karena suatu profesi memerlukan kemampuan dan keahlian khusus dalam melaksanakan profesinya. Profesi juga diartikan sebagai suatu jabatan atau pekerjaan tertentu yang mensyaratkan pengetahuan dan keterampilan khusus yang diperoleh dari pendidikan akademis yang intensif. Jadi profesi adalah suatu pekerjaan atau jabatan yang menuntut keahlian tertentu. Artinya suatu pekerjaan atau jabatan yang disebut sebagai profesi tidak dapat dipegang oleh sembarang orang, tetapi memerlukan persiapan melalui pendidikan dan pelatihan secara khusus (Susanto, 2020: 13).

Berdasarkan pengertian di atas, meskipun profesi adalah karir seumur hidup dan ada konsekuensi ekonomis atas pekerjaan di bidang profesi tersebut, akan tetapi fokus utamanya terletak pada pengabdian dan tanggung jawab moril sesuai bidang keilmuan 
profesi. Dengan demikian tanggung jawab insan profesi bukan hanya kepada atasan atau pemerintah, melainkan juga pada bidang keilmuan dan kemanusiaan. Tanggung jawab tersebut juga menjadi pembeda antara profesi dengan bidang pekerjaan lain yang bukan profesi. Secara umum syarat suatu pekerjaan untuk dapat digolongkan menjadi suatu profesi yaitu: memiliki spesialisasi ilmu; memiliki kode etik dalam menjalankan profesi; memiliki organisasi profesi; diakui masyarakat; sebagai panggilan hidup; dilengkapi kecakapan diagnostik; dan mempunyai klien yang jelas (Susanto, 2020: 14-16).

Berdasarkan UU RI No.14 Tahun 2005 tentang Guru dan Dosen Pasal 1, Guru adalah pendidik profesional dengan tugas utama mendidik, mengajar, membimbing, mengarahkan, melatih, menilai, dan mengevaluasi peserta didik pada pendidikan anak usia dini jalur pendidikan formal, pendidikan dasar, dan pendidikan menengah. Dosen adalah pendidik profesional dan ilmuan dengan tugas utama mentransformasikan, mengembangkan, dan menyebarluaskan ilmu pengetahuan, teknologi, dan seni melalui pendidikan, penelitian, dan pengabdian kepada masyarakat (Susanto, 2020: 16).

Guru merupakan suatu profesi, yang berarti suatu jabatan yang memerlukan keahlian khusus sebagai guru dan tidak dapat dilakukan oleh sembarang orang di luar bidang pendidikan. Walaupun pada kenyataannya masih terdapat guru yang tidak memiliki latar belakang pendidikan bidang keguruan (Susanto, 2020: 17).

\section{PERAN GURU SEBAGAI SEBUAH PROFESI}

Menurut National Education Association (NEA), syarat guru sebagai profesi terpenuhi karena memiliki kriteria:

1. Jabatan yang melibatkan kegiatan intelektual;

2. Jabatan yang menggeluti suatu batang tubuh ilmu yang khusus;

3. Jabatan yang memerlukan persiapan profesional yang lama (bandingkan dengan pekerjaan yang memerlukan latihan umum belaka);

4. Jabatan yang melibatkan memerlukan latihan dalam jabatan yang berkesinambungan;

5. Jabatan yang menjanjikan karier hidup dalam keanggotaan yang permanen;

6. Jabatan yang menentukan baku (standar) sendiri;

7. Jabatan yang lebih mementingkan layanan di atas keuntungan pribadi;

8. Jabatan yang mempunyai organisasi profesional yang kuat dan terjalin erat (Susanto, 2020: 19).

Guru merupakan satu di antara profesi di bidang pendidikan. Dalam UU No.14 Tahun 2005, dikatakan guru adalah pendidik profesional dengan tugas utama mendidik, mengajar, membimbing, mengarahkan, melatih, menilai, dan mengevaluasi peserta didik pada pendidikan usia dini jalur pendidikan formal, pendidikan dasar, dan pendidikan menengah. Guru dapat diartikan sebagai orang yang tugasnya terkait dengan upaya 
mencerdaskan kehidupan bangsa dalam semua aspeknya, baik spiritual dan emosional, intelektual, fisikal, maupun aspek lainnya (Susanto, 2020: 37).

Jika diidentifikasi dari filosofi pendidikan Indonesia yang dicetuskan oleh Ki Hadjar Dewantara "ing ngarso sung tulodo, ing madya mangun karso, tutwuri handayani” maka peran guru adalah sebagai:

1. Role model (ing ngarso sung tulodo), memberikan teladan kepada siswa karena fungsi guru menjadi pemimpin siswa dalam kegiatan pembelajaran.

2. Motor penggerak (ing madya mangun karso), guru harus menjadi penggerak inovasi dalam proses pendidikan dan penggerak peradaban dengan cara mengarahkan siswa untuk melakukan yang benar.

3. Motivator (tutwuri handayani), mampu memberikan dorongan semangat kepada siswa untuk menghadapi setiap persoalan dan mempelajari nilai-nilai kehidupan (Susanto, 2020: 38-39).

Dalam UU No.14 Tahun 2005 tentang Guru dan Dosen pada bagian kedua mengenai hak dan kewajiban pada pasal 14, adapun hak yang dimiliki oleh seorang guru adalah sebagai berikut:

1. Memperoleh penghasilan di atas kebutuhan hidup minimum dan jaminan kesejahteraan sosial.

2. Mendapatkan promosi dan penghargaan sesuai dengan tugas dan prestasi kerja.

3. Memperoleh perlindungan dalam melaksanakan tugas dan hak atas kekayaan intelektual.

4. Memperoleh kesempatan umtuk meningkatkan kompetensi.

5. Memperoleh dan memanfaatkan sarana dan prasarana pembelajaran untuk menunjang kelancaran tugas keprofesionalan.

6. Memiliki kebebasan dalam memberikan penilaian dan ikut menentukan kelulusan, penghargaan, dan sanksi kepada peserta didik sesuai dengan kaidah pendidikan, kode etik guru, dan peraturan perundang-undangan.

7. Memperoleh rasa aman dan jaminan keselamatan dalam melaksanakan tugas.

8. Memiliki kebebasan dalam berserikat dalam organisasi profesi.

9. Memiliki kesempatan untuk berperan dalam penentuan kebijakan pendidikan.

10. Memperoleh kesempatan untuk mengembangkan dan meningkatkan kualifikasi akademik dan kompetensi.

11. Memperoleh pelatihan dan pengembangan profesi dalam bidangnya (Susanto, 2020: 44-45).

Dalam melaksanakan tugas keprofesionalan dalam UU No.14 tahun 2005 tentang Guru dan Dosen, pada pasal 20 maka guru berkewajiban sebagai berikut:

1. Merencanakan pembelajaran, melaksanakan proses pembelajaran yang bermutu, serta menilai dan mengevaluasi hasil pembelajaran. 
2. Mengembangkan dan meningkatkan kualifikasi akademik dan kompetensi secara berkelanjutan sejalan dengan perkembangan ilmu pengetahuan, teknologi, dan seni.

3. Bertindak objektif dan tidak diskriminatif atas dasar pertimbangan jenis kelamin, agama, suku, ras, dan kondisi fisik tertentu, atau latar belakang keluarga, dan status sosial ekonomi peserta didik dalam pembelajaran.

4. Menjunjung tinggi peraturan perundang-undangan, hukum, dank kode etik guru, serta nilai-nilai agama dan etika.

5. Memelihara dan memupuk persatuan dan kesatuan bangsa (Susanto, 2020: 48).

Bila dipahami, maka tugas guru tidak hanya sebatas dinding sekolah, tetapi juga sebagai penghubung antara sekolah dan masyarakat. Bahkan bila dirinci lebih jauh, tugas guru tidak hanya yang telah disebutkan. Menurut Roestiyah N.K., (1989) sebagaimana terkutip dalam Susanto (2020: 48-49) bahwa guru dalam mendidik anak didik bertugas untuk:

1. Menyerahkan kebudayaan kepada anak didik berupa kepandaian, kecakapan, dan pengalaman-pengalaman.

2. Membentuk kepribadian anak yang harmonis, sesuai cita-cita dan dasar negara kita Pancasila.

3. Menyiapkan anak menjadi warga negara yang baik sesuai undang-undang pendidikan.

4. Sebagai perantara dalam belajar. Di dalam proses belajar guru hanya sebagai perantara/medium, anak harus berusaha sendiri mendapatkan suatu pengertian, sehingga timbul perubahan dalam pengetahuan, tingkah laku, dan sikap.

5. Guru adalah sebagai pembimbing, untuk membawa anak didik kearah kedewasaan, tidak dapat membentuk anak menurut sekehendaknya.

6. Guru sebagai penghubung antar sekolah dan masyarakat. Anak nantinya akan hidup dan bekerja, serta mengabdikan diri dalam masyarakat, dengan demikian anak harus dilatih dan dibiasakan di sekolah di bawah pengawasan guru.

7. Sebagai penegak disiplin, guru menjadi contoh dalam segala hal, tata tertib dapat berjalan bila guru dapat menjalani terlebih dahulu.

8. Guru sebagai administrator dan manajer. Di samping mendidik, seorang gur harus dapat mengerjakan urusan tata usaha seperti membuat buku kas, daftar induk, rapor, daftar gaji dan sebagainya, serta dapat mengkoordinasi segala pekerjaan di sekolah secara demokratis, sehingga suasana pekerjaan penuh dengan rasa kekeluargaan.

9. Pekerjaan guru sebagai suatu profesi.

10. Guru sebagai perencana kurikulum. Guru menghadapi anak-anak setiap hari, gurulah yang paling tau kebutuhan anak-anak dan masyarakat sekitar, maka dalam penyusunan kurikulum, kebutuhan ini tidak boleh ditinggalkan. 
11. Guru sebagai pemimpin (guidance worker). Guru mempunyai kesempatan dan tanggung jawab dalam banyak situasi untuk membimbing anak ke arah pemecah soal, membentuk keputusan, dan menghadapkan anak-anak pada problem.

12. Guru sebagai sponsor dalam kegiatan anak-anak. Guru harus turut aktif dalam segala aktivitas anak, misalnya ekstrakurikuler membentuk kelompok belajar dan sebagainya.

Dengan poin-poin yang telah disebutkan di atas maka alangkah lebih baiknya kita dapat menghargai guru dengan lebih baik lagi, karena yang kita pahami bahwa banyaknya tugas guru yang dilakukan yang mana bukan hanya untuk mendidik tetapi juga berbagai macam hal lainnya (Susanto, 2020: 49).

\section{GURU INDONESIA DAN TANTANGAN PROFESIONALISME}

Dalam upaya pembangunan pendidikan nasional, sangat diperlukan guru (pendidik) dalam standar mutu kompetensi dan profesionalisme yang terjamin. Untuk mencapai jumlah guru profesional yang dapat menggerakan dinamika kemajuan pendidikan nasional diperlukan suatu proses pembinaan berkesinambungan, tepat sasaran dan efektif. Proses menuju guru profesional ini perlu didukung oleh semua unsur yang terkait dengan guru. Unsur-unsur tersebut dapat dipadukan untuk menghasilkan suatu sistem yang dapat dengan sendirinya bekerja menuju pembentukan guru-guru yang profesional dalam kualitas maupun kuantitas yang mencukupi (Mustofa, 2007: 76).

Menurut Wardani (2012) kemampuan profesional sebagai guru termasuk dalam penguasaan sosok utuh dari implementasi kompetensi guru serta kemampuan melaksanakan tugas dengan mengutamakan kebaikan dan kepuasaan peserta didik. Menurut Putri dan Imaniyati (2017) profesi pendidik ialah profesi yang sangat berperan dalam kehidupan suatu bangsa dikarenakan kedudukan pendidikan yang sangat penting dalam konteks kehidupan bangsa. Pendidik merupakan unsur dominan atau komponen yang paling berperan dalam suatu proses pendidikan sehingga kualitas pendidikan banyak dipengaruhi oleh kualitas dari pendidik itu sendiri dalam menjalankan peran dan tugasnya di masyarakat. Maka dari itu mengembangkan profesi pendidik menjadi ketentuan mutlak bagi proses memajukan suatu bangsa, meningkatnya kualitas pendidik juga akan mendorong pada peningkatan kualitas pendidikan baik dari segi proses maupun hasil (Ratnasari, 2019: 236).

Yusutria (2017) menyatakan bahwa guru sebagai pendidik profesional memiliki gambaran yang baik di mata masyarakat dengan cara mampu menunjukkan kepada masyarakat bahwa ia pantas untuk dijadikan sebagai panutan oleh sekelilingnya terutama oleh masyarakat yang akan melihat perilaku dan perbuatan guru dalam kesehariannya. Profesionalisme guru menjadi perhatian secara global, karena guru tidak hanya bertugas dan berperan sebagai pemberi informasi ilmu pengetahuan dan teknologi, melainkan juga 
mampu membentuk sikap serta jiwa yang dapat bertahan dan bersaing dalam era globalisasi (Ratnasari, 2019: 236).

Berdasarkan analisis data dari Fitriana (2014), untuk meningkatkan profesionalisme guru dapat dilakukan dengan cara: (1) melakukan supervisi yang dilakukan oleh supervisor dan senantiasa meningkatkan kedisiplinan; (2) penyediaan fasilitas yang memadai guna menunjang proses pembelajaran; (3) mengadakan rapat antar kepala sekolah dengan para guru; (4) melakukan penataran, seminar, pelatihan (workshop); (7) mengadakan kunjungan antar sekolah guna mengetahui pengetahuan maupun pengalaman dari guru-guru sekolah lain; dan (8) melakukan penelitian terkait dengan bidang pendidikan (Ratnasari, 2019: 237).

Guru merupakan profesi pendidik yang tergolong dalam tenaga professional maka dari itu profesi guru sangat penting dalam konteks kehidupan bangsa terutama pada peningkatan mutu pendidikan yang ada di Indonesia karena dengan adanya tenaga profesional dalam dunia pendidikan maka dalam pelaksanaannya dapat berjalan dengan baik sehingga mutu pendidikan di Indonesia dapat meningkat (Ratnasari, 2019: 237).

Dengan mengingat berat dan kompleksnya membangun pendidikan, adalah sangat penting untuk melakukan upaya-upaya guna mendorong dan memberdayakan tenaga pendidik untuk semakin profesional. Hal ini tidak lain dimaksudkan untuk menjadikan upaya membangun pendidikan kokoh, serta mampu untuk terus menerus melakukan perbaikan ke arah yang lebih berkualitas (Mustofa, 2007: 77).

Kompetensi secara sederhana dapat diartikan sebagai paket kemampuan yang menunjukkan perpaduan antara pengetahuan, sikap, dan keterampilan dalam suatu bidang. Tiga aspek tersebut merupakan satu kesatuan yang membentuk kompetensi, sehingga seseorang dapat dikatakan kompeten apabila menunjukkan penguasaan ketiganya (Susanto, 2020: 62).

Guru dituntut memiliki kompetensi keguruan dimana di dalamnya terdapat kompetensi pedagogik, kompetensi kepribadian, kompetensi sosial, kompetensi profesional, dan kompetensi kepemimpinan. Salah satu kompetensi yang tidak kalah penting dari kompetensi lainnya yaitu kompetensi profesional dimana seorang guru sebagai tenaga profesional haruslah berkompeten saat menerapkan sejumlah konsep dan juga menunjukkan keterampilan kerjanya baik di lingkungan sekolah maupun di luar sekolah serta dapat menginterpretasikan pengalaman-pengalaman yang dimiliki dengan tujuan agar kinerja dari guru tersebut dapat efektif dan efisien. Kompetensi profesional sendiri dapat dijadikan sebagai wadah bagi guru untuk meningkatkan kualitas dirinya sendiri (Ratnasari, 2019: 238).

Beberapa usaha yang dapat dilakukan dalam meningkatkan profesionalisme guru yaitu dengan berbagai cara melakukan supervisi yang dilakukan oleh supervisor dan senantiasa meningkatkan kedisiplinan, penyediaan fasilitas yang memadai guna menunjang proses pembelajaran, mengadakan rapat antar kepala sekolah dengan para guru, melakukan penataran, seminar, pelatihan (workshop), mengadakan kunjungan antar sekolah guna 
mengetahui pengetahuan maupun pengalaman dari guru-guru sekolah lain, dan melakukan penelitian terkait dengan bidang pendidikan dengan melihat permasalahan pendidikan yang masih perlu adanya pemecahan masalah. Upaya peningkatan profesionalisme guru dapat dilakukan dengan melakukan pelatihan-pelatihan mengenai pemanfaatan teknologi dimana saat ini guru sebagai tenaga profesional harus memiliki kemampuan dalam menggunakan teknologi agar tidak tertinggal serta dapat bersaing dengan guru lain (Ratnasari, 2019: 238).

\section{SIMPULAN}

Berdasarkan UU RI No.14 Tahun 2005 tentang Guru dan Dosen Pasal 1, Guru adalah pendidik profesional dengan tugas utama mendidik, mengajar, membimbing, mengarahkan, melatih, menilai, dan mengevaluasi peserta didik pada pendidikan anak usia dini jalur pendidikan formal, pendidikan dasar, dan pendidikan menengah. Dosen adalah pendidik profesional dan ilmuan dengan tugas utama mentransformasikan, mengembangkan, dan menyebarluaskan ilmu pengetahuan, teknologi, dan seni melalui pendidikan, penelitian, dan pengabdian kepada masyarakat (Susanto, 2020: 16).

Dengan mengingat berat dan kompleksnya membangun pendidikan, adalah sangat penting untuk melakukan upaya-upaya guna mendorong dan memberdayakan tenaga pendidik untuk semakin profesional. Hal ini tidak lain dimaksudkan untuk menjadikan upaya membangun pendidikan kokoh, serta mampu untuk terus menerus melakukan perbaikan ke arah yang lebih berkualitas (Mustofa, 2007: 77).

Guru dituntut memiliki kompetensi keguruan dimana di dalamnya terdapat kompetensi pedagogik, kompetensi kepribadian, kompetensi sosial, kompetensi profesional, dan kompetensi kepemimpinan. Salah satu kompetensi yang tidak kalah penting dari kompetensi lainnya yaitu kompetensi profesional dimana seorang guru sebagai tenaga profesional haruslah berkompeten saat menerapkan sejumlah konsep dan juga menunjukkan keterampilan kerjanya baik di lingkungan sekolah maupun di luar sekolah serta dapat menginterpretasikan pengalaman-pengalaman yang dimiliki dengan tujuan agar kinerja dari guru tersebut dapat efektif dan efisien. Kompetensi profesional sendiri dapat dijadikan sebagai wadah bagi guru untuk meningkatkan kualitas dirinya sendiri (Ratnasari, 2019: 238).

\section{REFERENSI}

Efendi, I., Prawitasari, M., \& Susanto, H. (2021). Implementasi Penilaian Pembelajaran Pada Kurikulum 2013 Mata Pelajaran Sejarah. Prabayaksa: Journal of History Education, 1(1), 21-25. 
Mustofa. (2007). Upaya Pengembangan Profesionalisme Guru Di Indonesia. Jurnal Ekonomi \& Pendidikan , 4(1), 76-88.

Ratnasari, Yulia Triana. (2019). Profesionalisme Guru Dalam Peningkatan Mutu Pendidikan. Prosiding dari Seminar Nasional Jurusan Administrasi Pendidikan Fakultas Ilmu Pendidikan Universitas Negeri Malang dengan tema Revitalisasi Manajemen Pendidikan Anak Usia Dini (PAUD) di Era Revolusi Industri 4.0: 235239.

Susanto, H. (2020). Profesi Keguruan. Banjarmasin: FKIP Universitas Lambung Mangkurat.

Susanto, H., \& Akmal, H. (2018). Efektivitas Penggunaan Aplikasi Pembelajaran Berbasis Mobile Smartphone Sebagai Media Pengenalan Sejarah Lokal Masa Revolusi Fisik Di Kalimantan Selatan Pada Siswa Sekolah Menengah Atas. HISTORIA: Jurnal Program Studi Pendidikan Sejarah, 6(2), 197-206.

Susanto, H., Irmawati, I., Akmal, H., \& Abbas, E. W. (2021). Media Film Dokumenter Masuknya Islam Ke Nusantara dan Pengaruhnya Terhadap Keterampilan Berpikir Kritis Siswa. HISTORIA: Jurnal Program Studi Pendidikan Sejarah, 9(1).

Syaharuddin, S., \& Susanto, H. (2019). Sejarah Pendidikan Indonesia (Era Pra Kolonialisme Nusantara sampai Reformasi). Banjarmasin: FKIP Universitas Lambung Mangkurat. 